\title{
Histological Structure of The Proventriculus in Pupal and Adult Stages of Queen and Worker Yemen Honey Bee, Apis mellifera jementica, Ruttner
}

\author{
Aljedani, D. M. ${ }^{1}$, Almehmadi, R. M. ${ }^{{ }^{*}}$ and Al-Ghamdi, A. A ${ }^{\mathbf{2}}$ \\ ${ }^{1}$ Department of Biology, Faculty of Sciences-AL Faisaliah Campus, King Abdul-Aziz University. \\ ${ }^{2}$ Engineer Abdullah Buqshan Chair for Bee Research - College of food and Agriculture Science- \\ King Saud University. Saudi Arabia \\ P.O. Box 19516 Jeddah 21445 \\ *Email: D_almehmadi@yahoo.com
}

Received on: 18/11/2015

Accepted: 29/2/2016

\begin{abstract}
This histological study of the proventriculus of the Yemen honey bees, Apis mellifera jementica illustrates the complexity of this structure. It was differences found between queens and workers, as well as between different stages within the same caste. The proventriculus has growth degrees in the different growth stages during metamorphosis. For queens, the first to third day of pupal stage, were studied, whereas virgin worker pupae were observed at days one, four and seven. In addition, queens and workers were examined throughout the adult stage. The results indicated that the proventriculus tissue in the pupal stage is characterized by reformation of the foregut (crop and proventriculus), with the proventriculus gaining spines, teeth and a noticeably thicker chitin layer. The adult stage is characterized by caste-specific tissue changes based on food type. Furthermore, in adults, the proventriculus terminates with four moving, triangularshaped flanges fitted with a number of spines and teeth and covered by a thick layer of chitin.
\end{abstract}

Key words: : Apis mellifera jemenatica, Proventriculus, Queen, Worker, Histology.

\section{INTRODUCTION}

The internal anatomy and histology of the insect digestive canal can differ from one species to another. In holometabolous insects, the structure of the digestive canal is markedly different during larval and adult stages. In the honey bee (Apis mellifera), the larval digestive canal consists of a foregut with an esophageal valve, a midgut and a hindgut (including the ileum and rectum) (Snodgrass, 1984). In the adult, the digestive canal consists of a foregut (including the pharynx, esophagus, crop, and proventriculus, a midgut with a differentiation of the pyloric valve area, and a hindgut (including the pyloric valve, ileum and rectum) (Snodgrass, 1984; Cruz-Landim, 1985). Apis mellifera jemenatica (honey bee) is considered to be a beneficial insect in the holy Quran. Aljedani, et al., (2010), Almehmadi, et al., (2010), and AlGhamdi, et al., (2010) studied the histological structure of the crop at various stages in both queens and worker bee castes (Apis mellifera jemenatica). However, there is a lack of reports describing the proventriculus in honey bees, and in particular the morphological changes in histological structures during different growth stages, which prompted us to perform this study in Apis mellifera jemenatica.

\section{MATERIALS AND METHODS}

A preliminary survey was conducted to determine suitable apiary sites in the western region of the Kingdom of Saudi Arabia. The selected apiary was located at the Hada Al-Sham research station, $110 \mathrm{~km}$ northeast of Jeddah city. This location is a typical agricultural research station in the Kingdom and belongs to the Faculty of Meteorology, Environment and Arid Land Agriculture of King Abdul-Aziz University. Local Yemeni bee races (Apis mellifera jemenatica), which is the smallest race of yellow bees, were selected for the present study. The most obvious distinguishing morphological characteristics in this race are that worker bees have relatively short wings and legs and have yellow rings on their abdomens, whereas queens have relatively large yellow abdomens. Two medium-sized hives of local pure bees were used to collect individuals from different castes at different ages for anatomical and histological studies.

1. Individuals used in the study:

A- Pupae: The age (in days) of the pupal stages was determined by changes in body and eye color. For queens, one, two and three day-old pupae were selected, and for workers, one, four and seven dayold pupae were selected. 
B-Queens: Newly emerged adult queens (virgin queens)were selected for this study.

C-Workers: Adult workers were examined at three age levels that varied by the type of food consumed. For newly emerged workers, the age levels were as follows: $0-12$ hours prior to the onset of feeding, nurse workers which consume large amounts of the pollen stored inside the hexagonal cells, particularly over days 3-6 (protein feeding), and foragers which collect and feed on nectar and pollen, and they consume a larger amount of nectar than the nurse bees (carbohydrate feeding).

\section{Determining ages in worker bees:}

One comb was selected and dated, containing one-day-old eggs . After three days, the eggs hatched, and larvae continued to develop over five instars (13 days after oviposition or 6 days after the hexagonal cells are covered), then became pupae (one-day-old pupae). Worker bee age was determined by identifying newly emerged worker bees (either during exit from a cell, or immediately after exit) on a brood frame. A temperature of $33{ }^{\circ} \mathrm{C}$ and a relative humidity of $65 \%$ were used to obtain 24-hour-old workers. The newly emerging worker bees were marked with colored markers to track the different ages.

\section{Honey bee queen breeding:}

Waxy cups grafting method (also known as the Doolittle), method was used to breed and obtain queens of different ages.

\section{Histology:}

The histological study samples were collected from individuals that had not been exposed to any abnormal treatments and were free from injury. Individuals were allowed to feed naturally, and an average of 10 individuals of each age were collected and placed in a preservative solution. The samples used for histology were prepared after dissection and separation of the whole gut. The proventriculus portion was fixed using the following steps: washing, dehydration, clarification, landfill, trimming and staining with dyes (hematoxylin and eosin), according to common methods (Alhaji, 1998). Samples were then examined and photographed using an Olympus microscope (Olympus-Bx41).

\section{Pupal stage. \\ 1- A. Queens:}

The proventriculus of a one-day-old queen pupa is characterized by a distention at the crop end and a flexion consisting of a group of elongated epithelial cells(Epth), with a nuclei $(\mathrm{Nu})$ elongated centrally at almost the same level. The inside of the proventriculus is lined with a layer of chitin $(\mathrm{Ch})$ and is thick with few scleroses. The outside is surrounded by a layer of muscle (M) (Fig. 1, A \& B). The proventriculus of a two-day-old queen pupa is occupying a large area of crop. It is similar to that of the first day, although the Epth cells are shorter, and the Ch layer is thicker and with sharper teeth $(\mathrm{T})$ and spines $(\mathrm{S})$. The outside is surrounded by a distinct $M$ layer (Fig. 1, $C \& D$ ). The stomodaeum valve is more developed than first day. The proventriculus of three-day-old queen pupa is similar to that of the second day, although the Epth cells are shorter, and the $\mathrm{Ch}$ layer is thicker with sharper $\mathrm{T}$ and $\mathrm{S}$, The outside is surrounded by a distinct $\mathrm{M}$ layer (Fig. 1, E \& F).

\section{1- B. Workers:}

The proventriculus of a one-day-old worker pupa has an elongated Epth cell layer without clearly centralized $\mathrm{Nu}$ and is lined with a $\mathrm{Ch}$ layer adjacent to the cells. The $\mathrm{Ch}$ layer is thinner than in one-day-old queen pupae and also displays bristles. The outside of the proventriculus is surrounded by a $\mathrm{M}$ layer (Fig. 2, A \& B). The proventriculus of a four-day-old worker pupa has an Epth cell layer that is shorter than in one-day-old worker pupae, and the $\mathrm{Ch}$ layer is thicker with distinct teeth and more thorns. The outside is surrounded by a M layer (Fig. 2, C\& D). The 7-day-old worker pupae had proventriculi that were similar to those found in four-day-old pupae, although they had a harder $\mathrm{Ch}$ layer and the M layer occupied more space (filling the flexion) (Fig. 2, E \& F).

2. Adult stage:

2- A. Queen: The proventriculus is a short portion of the alimentary canal, and is a link between the crop and the midgut. The front of the proventriculus is enclosed by the crop. A cross section of the proventriculus showed that its end has four moving, triangular-shaped flanges with a number of spines (s) and teeth (T).

When the four flanges (considered to be the proventriculus mouth) are closed, they form an $\mathrm{x}$ shape, and in the open position, they push into the crop wall. These four flanges represent the end of the thick triangular flexion emerging from the proventriculus wall, and they consist of a splayed layer of Epth cells with clear $\mathrm{Nu}$ and a thick $\mathrm{Ch}$ layer. Each flection contains a large bundle of longitudinal muscle ( $\mathrm{L}$ muscle) fibers, and the whole organ is surrounded by thick circular muscle (C muscle) fibers (Fig. 3, A, B, C \& D).

2- B. Workers: The proventriculus of a newly emerged honey bee worker is not significantly different from that of a queen of the same age (Fig. 3, E \& F). The proventriculus of a nurse workers is similar to that of foragers; however, the lining has a thicker $\mathrm{Ch}$ layer, more $\mathrm{T}$, and a thicker M layer (Fig. 4, A, B, C \& D)and The proventriculus of a foragers has flexions with thick ends and is oversized and broad. The Epth layer is more distinct and elongated with clear $\mathrm{Nu}$, and the inside has a thicker $\mathrm{Ch}$ layer, more T, and a thicker M layer (Fig. 4, E, F, G \& H). 

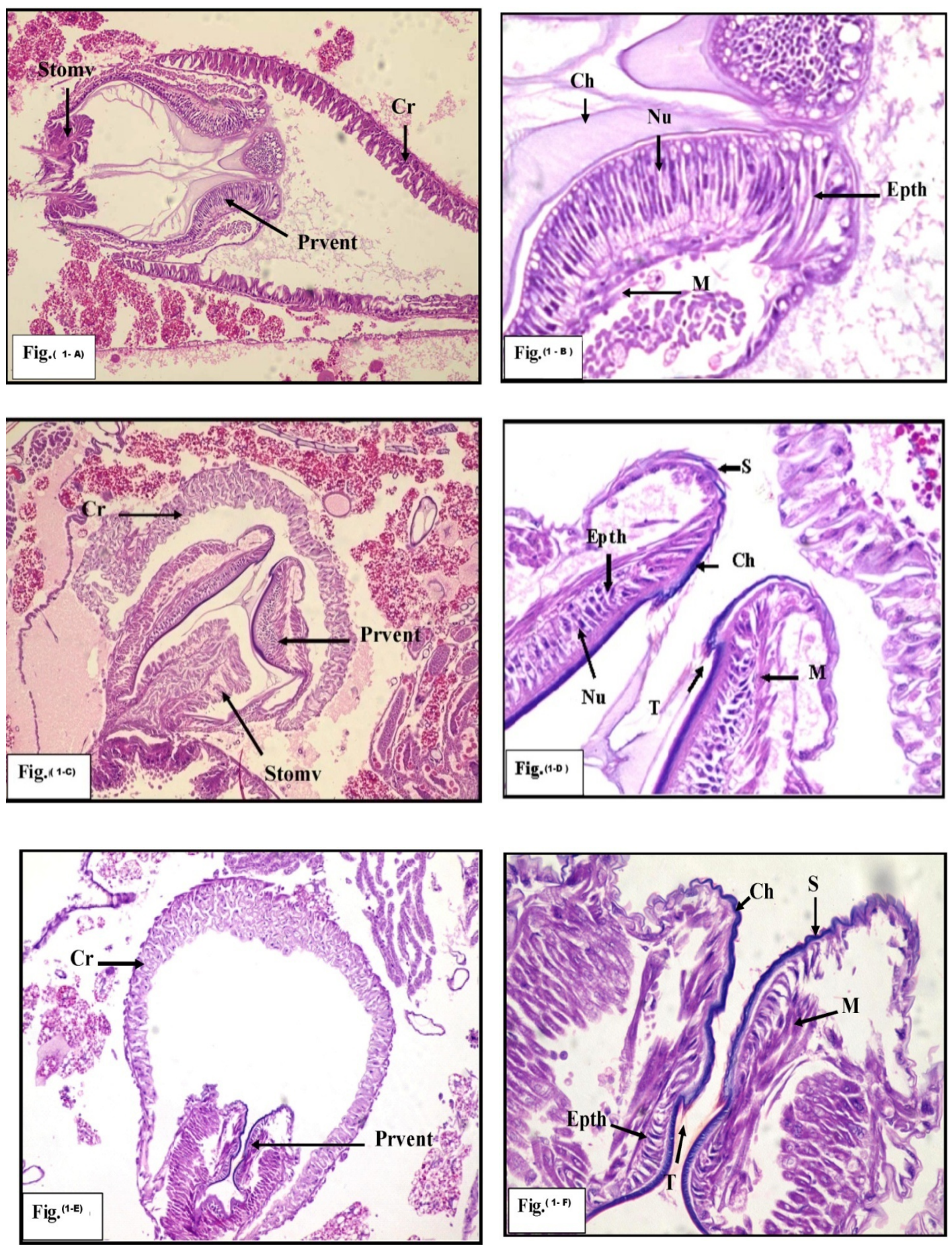

Fig. 1: Longitudinal section of the proventriculus. A (x 100), B (x 400) 1-day-old honey bee queen pupa. C (x 100), D (x 400) 2-day-old queen pupa. E (x 100), F (x 400) 3-day-old queen pupa. Ch: chitin. Cr: crop. Epth: epithelial cells. M: muscles. Nu: nucleus. Prvent: proventriculus. Stomv: stomodaeum valve. S: spines. T: teeth. 

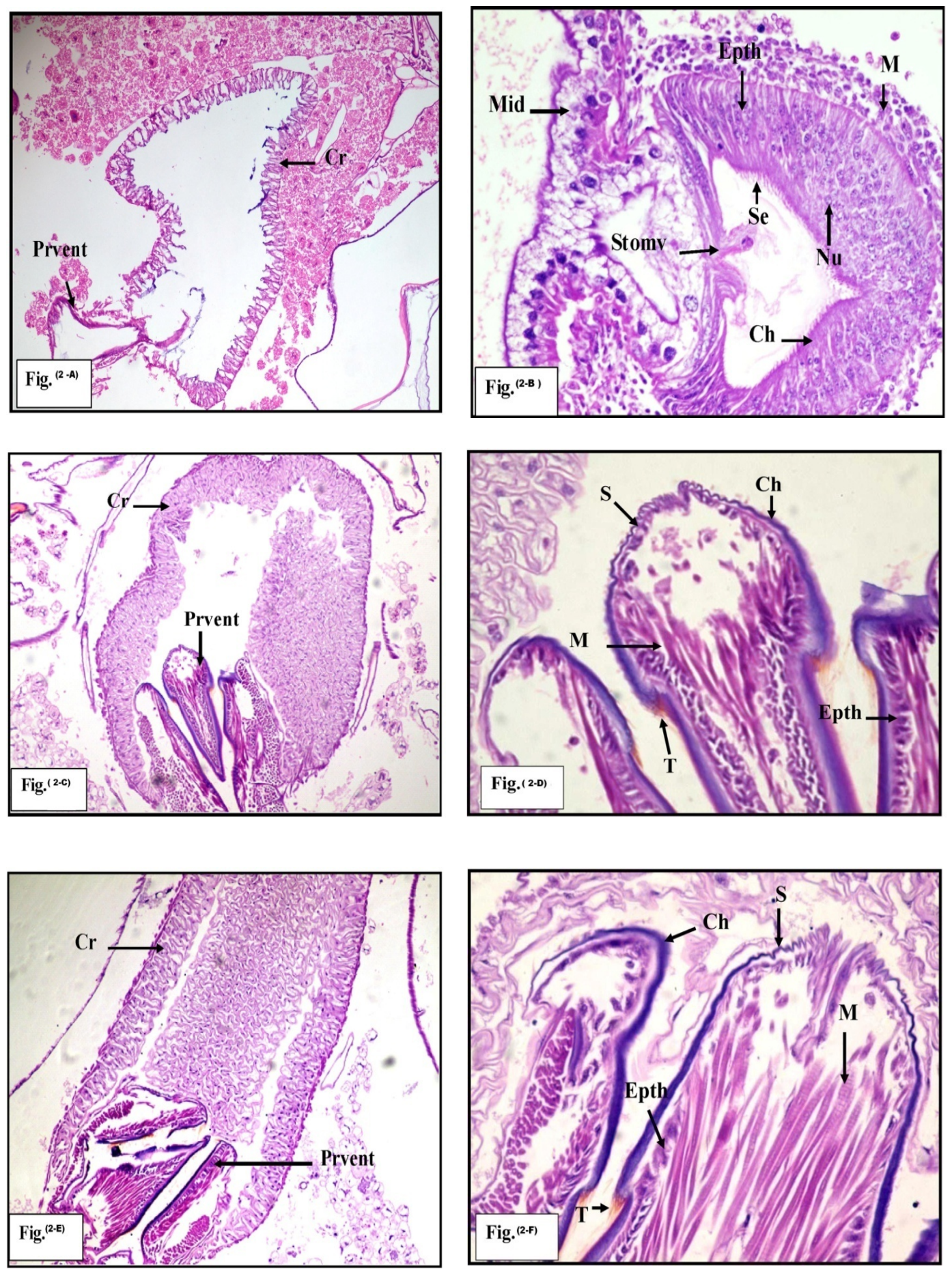

Fig. 2: Longitudinal section of the proventriculus. A (x 100), B (x 400) 1-day-old honey bee worker pupa. C (x 100), D (x 400) 4-day-old worker pupa. E (x 100), F (x 400) 7-day-old worker pupa. Ch: chitin. Cr: crop. Epth: epithelium cells. Mid: midgut. M: muscles. Nu: nucleus. Prvent: proventriculus. Se: seta. Stomv: stomodaeum valve. S: spines. T: teeth. 

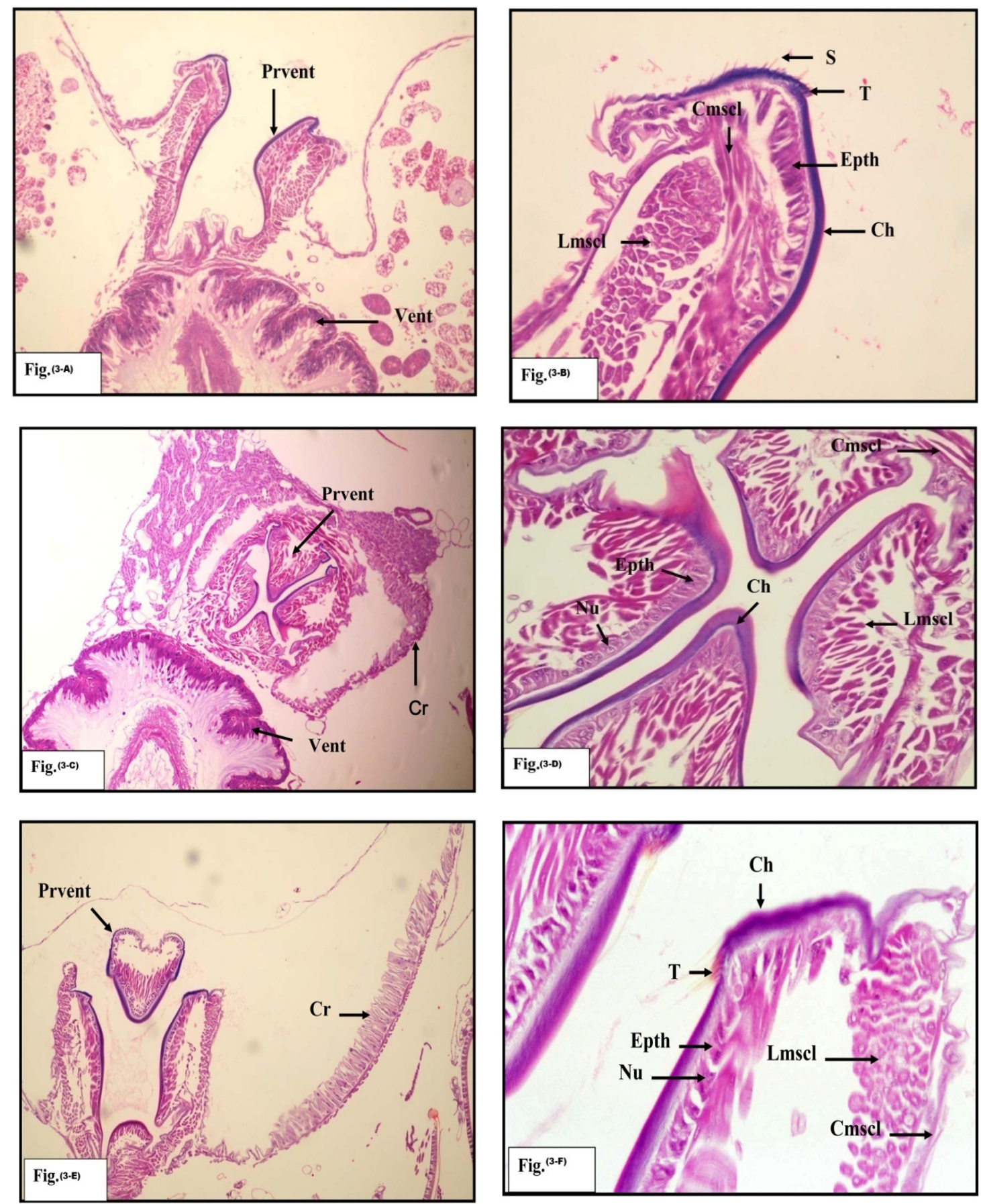

Fig. 3: A (x 100), B (x 400) Longitudinal section of the proventriculus of a virgin queen honey bee. $C$ ( $x$ 100), D ( $x$ 400) Cross section of the proventriculus of a virgin queen. $E$ ( $x$ 100), $F(x$ 400) Longitudinal section of the proventriculus of a newly emerged honey bee worker. Ch: chitin. Cmscl: circular muscles. Cr: crop. Epth: epithelial cells. Lmscl: longitudinal muscles. Nu: nucleus. Prvent: proventricular valve. S: spines. T: teeth. Vent: ventriculus. 

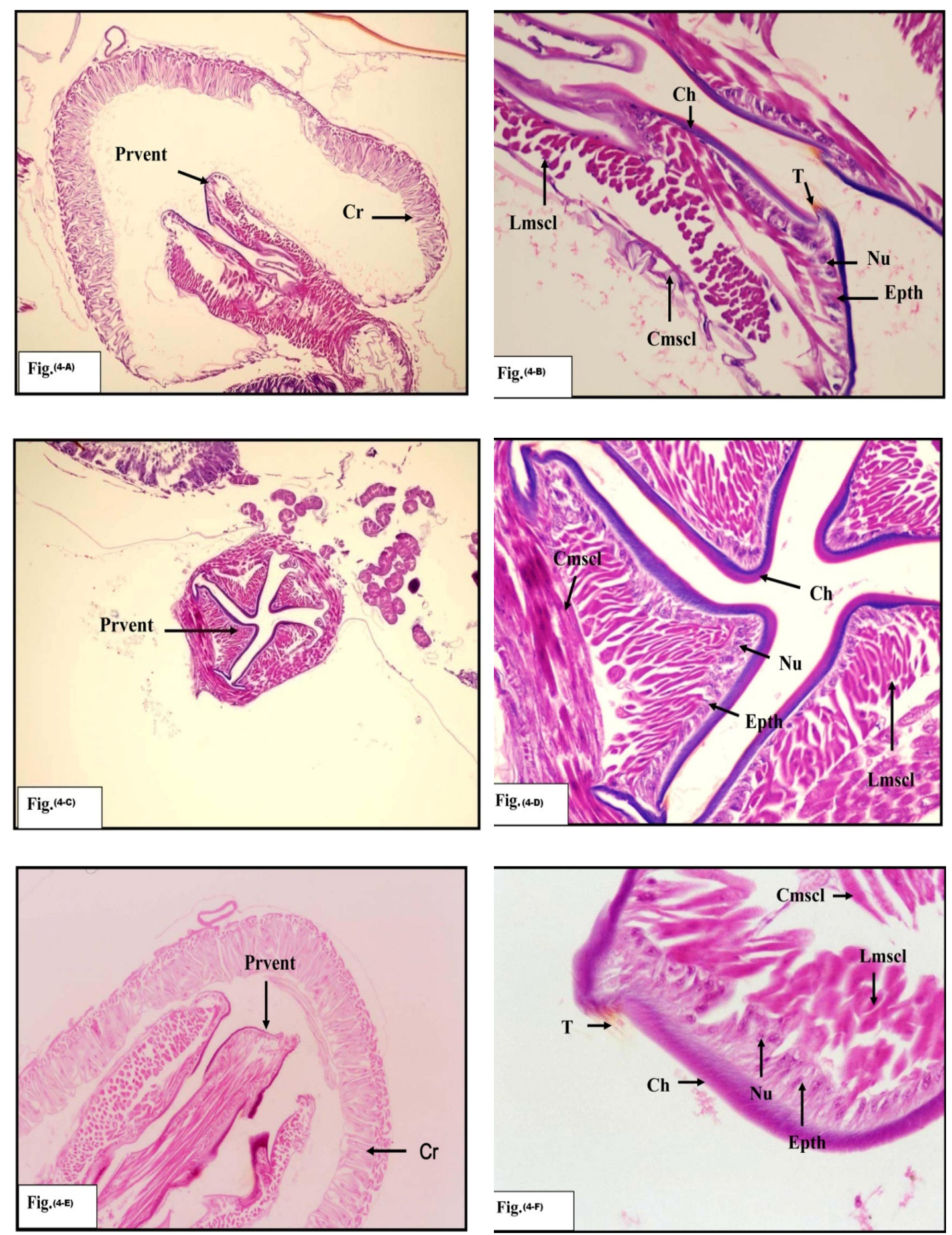

Fig. 4: A (x 100), B (x 400) Longitudinal section of the proventriculus in a nurse honey bee. C (x 100), D ( $x$ 400) Cross section of the proventriculus in a nurse honey bee. $E$ (x 100), F (x 400) Longitudinal section of the proventriculus in a forager honey bee. Ch: chitin. Cmscl: circular muscles. Cr: crop. Epth: epithelial cells. Lmscl: longitudinal muscles. Nu: nucleus. Prvent: proventricular valve. T: teeth. 

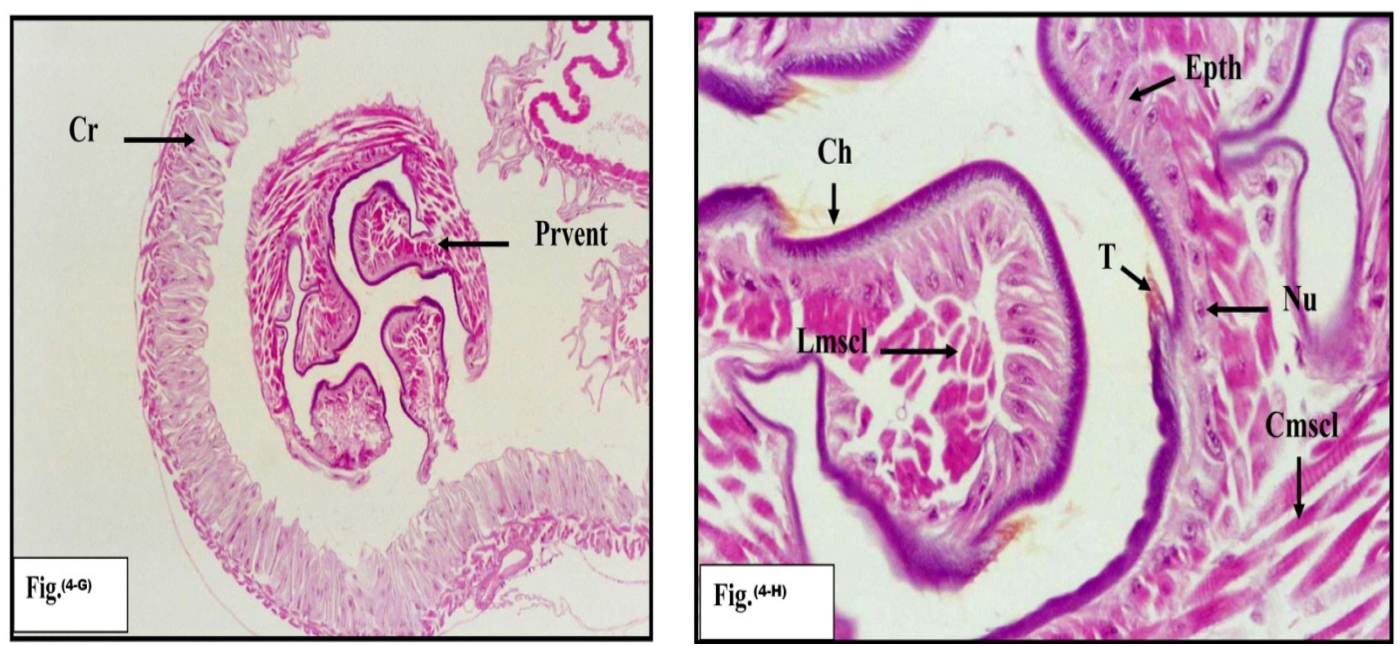

Cont. Fig. 4: G (x 100), H (x 400) Cross section of the proventriculus in a forager honey bee. Ch: chitin.

Cmscl: circular muscles. Cr: crop. Epth: epithelial cells. Lmscl: longitudinal muscles. Nu: nucleus.

Prvent: proventricular valve. T: teeth.

\section{DISCUSSION}

This histological study of the proventriculus of the Yemen honey bee (Apis mellifera jemenatica) illustrates the complexity of this structure. Differences were found between queens and workers, as well as between different life stages within the same caste. In worker pupae, the proventriculus muscle layer, chitin layer, spines and teeth are thicker than in queen pupae, which is likely due to differences in the types of food consumed during the adult stage. The primary role of the proventriculus in workers is to separate pollen and prevent food from returning to the foregut. Another function of the proventriculus in workers is to regulate the movement of food from the crop to the midgut, and the proventriculus also functions as the mouth of the ventriculus (EL-Ansari 2007). Indeed, the proventriculus wall features a group of muscles that help to control its opening and closing, allowing or preventing food to pass into the ventriculus (Hefny 2005). The results of the present study indicate that the proventriculus structure in queens and newly emerged workers are simple structures with relatively short cells and thin muscle and chitin layers, consistent with the fact that these stages feed on foods with simple compositions. In nurse bees, the chitin layer is thicker and the teeth are more numerous because they feed on pollen, whereas in foragers, the chitin and muscle layers are thicker than the nurse bees. This result is consistent with that of Chapman (1998), who reported that the proventriculus in bees is highly specialized and is able to separate suspended pollen in nectar inside the crop while retaining the nectar. The torsional movements of the proventriculus function in the dispersal and retention of pollen. The pollen bolus passes through the proventriculus to reach the midgut, and the nectar remains in the crop until the workers deposit it in hexagonal cells.

\section{REFERENCES}

Al-Ghamdi, A.A., Almehmadi, R.M. and Aljedani, D.M.(2010) Histology of ileum in Larval and Pupal Stages of the Queen and Worker Of Apis mellifera jemenatica(Hymenoptera: Apidae). Saudi Journal of Biological Sciences., Vol. 17, No(3):33-39.

Alhaj, H. A. (1998) preparations microscopic optical (microscopic technologies) the theoretical foundations and applications, the first edition: Jordanian books Center, Amman, Jordan., 331 pp.

Aljedani, D.M., Alghamdi, A.A. and Almehmadi R.M.(2010) Comparative Study in Midgut Histological Structure of Queen and Worker Yemeni Honey Bees Apis mellifera jemenatica (Hymenoptera: Apidae) in Pupae and Adult Stages Under Natural Nutrition. Ass.Univ. Bull. Environ.Res.,Vol. 13. No. (2): 63-76.

Almehmadi R.M., Alkhazim A.A. and Aljedani D.M. (2010) Comparative study on histological structure of larval midgut in Queen and workers of native honey bee race (Apis mellifera jementica, Hymenopetra: Apidae.). Saudi Journal of Biological Sciences., Vol. 17, No( 3). 33-41.

Chapman, R.F. (1998) The Insects: Structure and Function, 4th ed. Cambridge Univesity Press: Cambridge., 819 pp.

Cruz-Landim,C.(1985) Ultra-estrutura e função do tubodigestivo dos insetos, Aciesp., 44: 2849. 
EL-Ansari, O. M. N. (2007) Encyclopedia of bees in honey production and crop pollination, Alexandria, Egypt: Knowledge facility in Alexandria. 1458 pp.
Hefny, A.M.(2005) beekeeping, Jeddah: Scientific Publishing Center- King Abdul Aziz University., $591 \mathrm{pp}$.

Snodgrass, R.E. (1984) Anatomy of the honeybee. Comstock Publishing Associates, A division of cornell university press .Ithaca and London. Fourth printing., 332 pp.

\section{الملخص العربى \\ التركيب النسيجي للقونصة لطور العذراء و الطور البالغ في ملكة وشغالة نحل العسل اليمني Apis mellifera jementica, Ruttner}

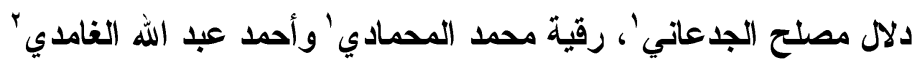

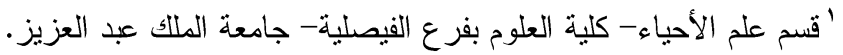

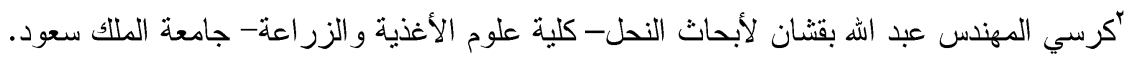

تتاولت هذه الدراسة التركيب النسيجي للقونصة لطور العذراء والطور البالغ لملكة وشغالة نحل العسل اليمني البلدي حيث أظهرت النتائج الدقة والإعجاز في التركيب لهذه الحشرة فقد وجدت اختلافات بين الملكة و الثغالة فيما بينهما وطور العذراء لكل منهما وكذلك اختلاف في الأعمار المختلفة لكل طور من أطوارهما. تمر القونصة وهنة بدرجات من النمو في أطوارها المختلفة خلال عملية التبدل وقد نم دراسة طور العذراء من اليوم الأول إلى الثالث

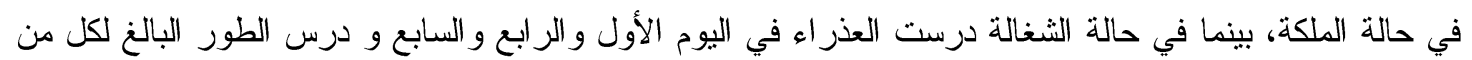

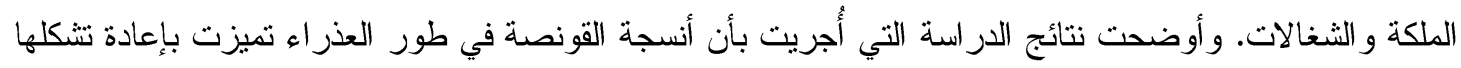

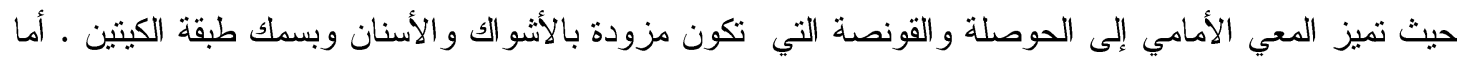
الطور البالغ تميزت أنسجته لنتتاسب مع الوظيفة التي تقوم بها و الغذاء الذي تتناوله حيث تنتهي بأربعة شُفيات متحركة مثلثة الشكل ومزودة بعدد من الأشو الك و الأسنان وتُبطنها طبقة سميكة من الكيتين. 